\title{
In situ DNA fragmentation during the re-establishment of desiccation tolerance in germinated seeds of Cedrela fissilis Vell. ${ }^{1}$
}

\author{
Tathiana Elisa Masetto ${ }^{2}$, José Marcio Rocha Faria ${ }^{3}$
}

\begin{abstract}
Dehydration is a necessary procedure prior to exposing seeds to long term storage, but this is associated with metabolism-linked injury mediated by cell injury. In order to assess cellular alterations during re-establishment of desiccation tolerance (DT) in C. fissilis germinated seeds and their relation to DNA damage, we verified the occurrence of DNA fragmentation through the TUNEL test and its evidence through the cytological analyses. To re-establish DT, germinated seeds were incubated for $72 \mathrm{~h}$ in polyethylene glycol (PEG, -2.04 MPa) before dehydration in silica gel (at 10\% moisture content) followed by rehydration. The moisture content changes during the reestablishment of the desiccation tolerance was accomplished. (DT)TdT-dUPT terminal nick-end labeling (TUNEL) was used to assess rates of cell death. TUNEL staining was performed using Click-iT-TUNEL Alexa Flour imaging assay. The TUNEL test showed a consistent DNA fragmentation in the 2 and $5 \mathrm{~mm}$ long radicles. Moreover, nuclear and chromosomal alterations were observed in the $5 \mathrm{~mm}$ meristematic root cell cycle, contributing to the identification of diagnostic markers of cell death.
\end{abstract}

Index terms: cell injury, moisture content, TUNEL test.

\section{Fragmentação de DNA in situ durante o restabelecimento da tolerância à dessecação em sementes germinadas de Cedrela fissilis Vell.}

\begin{abstract}
RESUMO - A desidratação é um procedimento necessário antes de expor as sementes ao armazenamento a longo prazo, mas isso está associado à lesão ligada ao metabolismo mediada por lesão celular. A fim de avaliar as alterações celulares durante o restabelecimento da tolerância à dessecação (TD) em sementes germinadas de C. fissilis e sua relação com danos no DNA, verificamos a ocorrência de fragmentação do DNA através do teste de TUNEL e suas evidências por meio da análise citológica. Para restabelecer o TD, as sementes germinadas foram incubadas por $72 \mathrm{~h}$ em polietilenoglicol (PEG, -2,04 MPa) antes da desidratação em sílica gel (a $10 \%$ de umidade) seguida de reidratação. O teor de água foi alterado durante o restabelecimento da tolerância à dessecação. Foi utilizado o rotulador TDT-dUPT (TUNEL) para avaliar as taxas de morte celular. A coloração TUNEL foi realizada usando o teste de imagem Click-iT-TUNEL Alexa Flour. O teste TUNEL mostrou uma fragmentação de DNA consistente nas radículas com 2 e 5 $\mathrm{mm}$ de comprimento. Além disso, alterações nucleares e cromossômicas foram observadas no ciclo celular meristemático de $5 \mathrm{~mm}$, contribuindo para a identificação de diagnósticos de marcadores de morte celular.
\end{abstract}

Termos para indexação: lesão celular, teor de água, teste de TUNEL.

\section{Introduction}

Understanding of the basis of seed desiccation sensitivity starts with knowledge of processes and mechanisms involved

\footnotetext{
${ }^{1}$ Submitted on 07/10/2018. Accepted for publication on 01/31/2019. ${ }^{2}$ Departamento de Ciências Agrárias, Universidade Federal da Grande Dourados, 79825-07 - Dourados, Mato Grosso do Sul, Brasil.
}

in the acquisition and maintenance of desiccation tolerance in orthodox seeds and studying whether or not these occur in recalcitrant types (Berjak and Pammenter, 2013). In orthodox seeds, metabolism is reduced to very low levels

${ }^{3}$ Departamento de Ciências Florestais, Universidade Federal de Lavras, 37200-000 - Lavras, Minas Gerais, Brasil.

*Corresponding author < tmasetto@gmail.com> 
and the embryo enters a state of quiescence, although remains responsive to environmental signals (Finch-Savage and Bassel, 2015; Leprince et al., 2017). In this way, even desiccation-tolerant seeds in the quiescent state may be affected by cellular deterioration when subjected to long-term storage. Cell damages arise from the combination of transitions between desiccation and rehydration, coupled with low cellular repair activities in the dried state. Together, these events lead to an accumulation of damage to macromolecules, including proteins, membrane lipids, and DNA (Waterworth et al., 2015).

Damage to DNA structure has been reported during ageing or drying of both desiccation-tolerant and intolerant seeds (Masetto et al., 2008; Kranner et al., 2011; Masetto et al., 2014; 2015; Dresch et al., 2015), suggesting that DNA fragmentation is linked to death, or that DNA degradation continues under standard seed storage conditions. However, changes of DNA that cause death (i.e. unrepaired breaks) are minor, compared to the damage that occurs after death (Walters et al., 2006). In this way, although the physiological and biochemical disorders that lead to growth inhibition of the root and of the whole plant are relatively well known (Farrant and Moore, 2011; Gechev et al., 2012; Challabathula et al., 2016), the alterations of DNA status, which represent the direct cause of seeds survival under abiotic stress and/or their capacity of resume their growth after rehydration, have not been explored to any great extent in seeds.

The terminal desoxynucleotide transferase mediated $d$-UTP nick-end labeling, or TUNEL, is a largely used sensitive method to evaluate the nuclear deformation during the apoptosis, in which the DNA degradation occurs, common in tissues that suffer cellular death (Liu et al., 2007). Germinated seeds of Cedrela fissilis Vell. (Meliaceae), a native tree from the Brazilian Atlantic Forest, have been used as a model to better understand the dessication tolerance, particularly the cytological assessment of the root tip provided evidence of the occurrence of cell death in the 2 and 5-mm-long radicles, which did not survive dehydration (Masetto et al., 2014). In order to assess cellular alterations during re-establishment of DT in C. fissilis germinated seeds and its relation to DNA damage, we verified the occurrence of DNA fragmentation through the TUNEL test and its evidence through the cytological analyses.

\section{Materials and Methods}

The seed collection and processing were carried out according to Masetto et al. (2014) from ripe fruits collected at the beginning of their dehiscence from about 20 trees in Lavras, South of Minas Gerais State (21 $\left.1^{\circ} 14^{\prime} \mathrm{S}, 45^{\circ} 00^{\prime} \mathrm{W}\right)$.
The evaluations after re-establishment of desiccation tolerance were carried out with germinated seeds with 1,2 and $5 \mathrm{~mm}$ long radicles that were chosen for moisture content and in situ DNA fragmentation investigations according to the previous results of Masetto et al. (2014) as follows: the germinated seeds with 1,2 and $5 \mathrm{~mm}$ radicle length were put in Petri dishes with a filter paper on the bottom, moistened with $20 \mathrm{~mL}$ of PEG 8000 solutions ( $380 \mathrm{~g}$ dissolved in $1 \mathrm{~L}$ water, according to Michel and Kaufmann, 1973) at $5{ }^{\circ} \mathrm{C}$ for $72 \mathrm{~h}$, which provided an osmotic potential of $-2.04 \mathrm{MPa}$. After that, the germinated seeds were washed in running water to remove the PEG solution residues, superficially dried on paper towel for $10 \mathrm{~min}$ and dehydrated in silica gel at $20^{\circ} \mathrm{C} / 60 \%$ RH. Samples were dried to the original seed moisture content $(10 \%)$, pre-humidified $\left(100 \% \mathrm{RH} / 24 \mathrm{~h} / 25^{\circ} \mathrm{C}\right)$ and rehydrated as described previously. Four independent experiments with 25 germinated seeds of each radicle length were carried out.

The moisture content changes during dehydration, pre-humification and rehydration were assessed in four replications of $2 \mathrm{~g}$ each, by oven-drying at $103 \pm 2{ }^{\circ} \mathrm{C}$ for 17 hours (Brasil, 2009) and expressed as percentage of moisture content on a fresh weight basis.

The terminal deoxynucleotide transferase mediated-dUTP nick-end labeling or TUNEL's reaction is used to evaluate the DNA fragmentation by the 3'-OH extremities detection of DNA strand, by the action of the terminal deoxynucleotide transferase enzyme, through the green fluorescence. It was used in agreement of the protocol instructions of the "APOBrdU $^{\mathrm{TM}}$ TUNEL Assay Kit” (Invitrogen - Molecular Probes) with Alexa Fluor. The 1, 2 and $5 \mathrm{~mm}$ long radicles fresh and PEG treated and dehydrated in silica at $10 \%$ of moisture content (three replications each) were fixed in paraformaldehyde at $1 \%$ for 12 hours. After this period, radicles were dehydrated in alcoholic gradient for 1 hour each $(30 \%, 50 \%, 70 \%, 90 \%$ and $100 \%$ ), fixed in Steedman's wax at $37 \%$, using one series of wax:ethanol (v:v) (50:50\%, 70:30\%, 90:10\%) and 100\% of wax every 1 hour. The radicles were sectioned longitudinally with $10 \mu \mathrm{m}$ thick using microtome and reactions were prepared according to the manufacturer. The images were observed with an epifluorescence microscope, utilizing $500 \mathrm{~nm}$ wave length (Olympus BX60).

In accordance to the previous results obtained through the TUNEL's reaction, the $5 \mathrm{~mm}$ long radicles, incubated in PEG 8000 , dehydrated in silica gel at $10 \% \mathrm{MC}$ and rehydrated, were chosen for cytological evaluation. Tips were collected, fixed in Carnoy's solution \{methanol:acetic acid - (3:1) \} and stored at $-20^{\circ} \mathrm{C}$ until the slide preparation. The radicle tips were taken from the fixative solution and washed in distilled water (5 minutes). Radicle tips were dried on filter paper and 
macerated in an enzymatic solution $\{2 \%$ cellulase (Sigma): $20 \%$ pectinase solution (Sigma) diluted in phosphate-citrate tampon $\mathrm{pH} 4.8\}$ at $37^{\circ} \mathrm{C}$ for 6 hours. After that, slides were prepared through the cellular dissociation technique, as described by Carvalho and Saraiva (1993). A total of 1000 cells were counted per slide, with two slides per Petri dish, totalizing ten slides and 10,000 cells analyzed.

\section{Results and Discussion}

The moisture content (MC) alterations from radicles during PEG incubation are presented on Figure 1. There was a remarkable reduction in the $\mathrm{MC}$ in radicles 1,2 and $5 \mathrm{~mm}$ length during the first 6 hours of PEG incubation. The $1 \mathrm{~mm}$ radicle reduced eight percentage points of $\mathrm{MC} ; 2 \mathrm{~mm}$ radicle length presented a reduction of nine percentage points and the 5-mm radicle length showed a reduction of 12 percentage points. After the first hours of PEG incubation, there was a subtle reduction of MC. After 72 hours, 1 and $2 \mathrm{~mm}$ radicle length presented, equally, $42 \% \mathrm{MC}$, while the $5-\mathrm{mm}$ radicle length presented 52\% MC (Figure 1A).

Changes in MC of the radicles submitted or not to the PEG treatment and dehydrated in silica gel are shown on Figure 1B. Both untreated and PEG treated radicles showed a similar pattern of MC reduction during the first 6 hours of dehydration in silica gel. As had already been observed for the moisture content from radicles, the 6 hours following dehydration, permitted noticing PEG-treated seedlings MC decrease at a constant until the end of the $24 \mathrm{~h}$ dehydration time, while the untreated radicles decrease moisture content during the whole drying period.

Notably, survival curves as a function of water content during drying showed an important loss of viability/integrity when the cells were dried below $10 \% \mathrm{MC}$, as seen by Masetto et al. (2014). Aside from the osmotic treatments improve the rate of water loss even in terms of method of drying, according to Leprince and Buitink (2010), there is also a need to understand the cause of damages occurring during drying. Understanding why these germinated seeds do not tolerate different levels of drying could be helpful to understand desiccation tolerance. The underlying mechanisms of the death of germinated orthodox seeds are less understood than the empirical description of the radicle length and the moisture content attained (Masetto et al., 2016). This is supported by the comparative analysis of the changes in $\mathrm{MC}$ of the PEG-treated and untreated C. fissilis radicles, during pre-humidification (for $24 \mathrm{~h}$ ) and the first $24 \mathrm{~h}$ of rehydration were similar (Figure 1C).

Along the first $12 \mathrm{~h}$ of pre-humidification, MC increased rapidly, and it was observed by the increase of about 4 percentage points in the radicles MC. It was observed that, during the first 24 hours of rehydration, the PEG-treated $1 \mathrm{~mm}$ long radicles showed a remarkable increase in water absorption when compared to untreated radicles of the same length. The other radicles ( 2 and $5 \mathrm{~mm}$ ) had a similar behavior during the pre-humidification and rehydration period, showing, at the end of 48 hours, $35 \% \mathrm{MC}$ average (Figure 1C). Despite their sensitivity to drying, the $\mathrm{PEG}+\mathrm{ABA}$ treated $1 \mathrm{~mm}$ long radicles were able to trigger a response involving $100 \%$ survival (Masetto et al., 2014), possibly validating further insights between survival and death which could lead to investigate
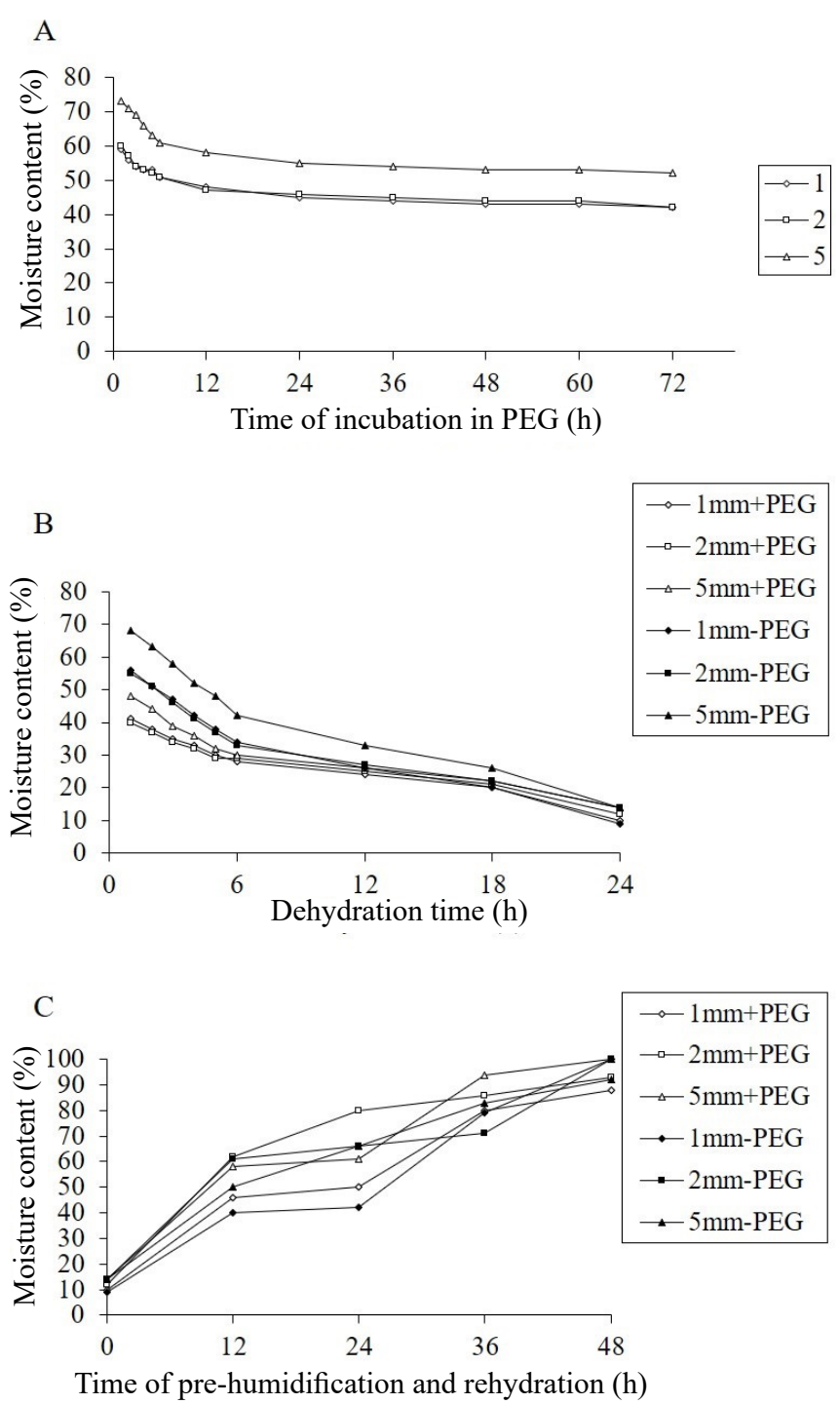

Figure 1. Changes in moisture content (MC) of Cedrela fissilis radicles during incubation in PEG (A), dehydration (B), pre-humidification and rehydration during $24 \mathrm{~h}(\mathrm{C})$. 
the changes in gene expression or protein abundance related to the hydration level at which tissues can survive (Leprince and Buitink, 2010).

It is well known that cellular macromolecules are protected by the reduced mobility of water and the capability of the cytoplasm to form a 'glassy' state (Bewley et al., 2013). However, the germinated seeds showed high moisture content (Figure 1A), and although the incidence of damage may be reduced with PEG treatment, as seen by Masetto et al. (2014), possibly, is the capacity for repair damages accumulated during dehydration has the potential to limit the cell survival after rehydration, according to the radicle length and the moisture content range.

In this way, the TUNEL test is largely applied to detect DNA degradation in situ and cellular death occurrence, resulting from the cell passive or programmed death. Additionally, to the results obtained from the DNA electrophoresis and from the cellular viability evaluation as seen by Masetto et al. (2014), TUNEL test detected the occurrence of DNA injury in 1,2 and $5 \mathrm{~mm}$ long radicles dehydrated, characterized by the green fluorescence of nucleus or TUNEL-positive (Figures $2 \mathrm{~A}, 2 \mathrm{~B}$ and $2 \mathrm{C}$, respectively).

Meristems nucleus from $1 \mathrm{~mm}$ long radicles, despite the fact of presenting a partial desiccation tolerance, as seen by Masetto et al. (2014), also presented loss of cellular viability after dehydration to $10 \% \mathrm{MC}$, characterized by TUNELpositive in less intensity (Figure $2 \mathrm{~A}$ ). Figures $2 \mathrm{~B}$ and $2 \mathrm{C}$ correspond to the meristem nuclei from 2 and $5 \mathrm{~mm}$ long radicles, respectively, and are highlightened by the green color, related to the loss of viability after dehydration. In this way, the DNA degradation observed in the present study was not related to internucleosomal fragmentation, as can be seen by the lack of DNA laddering in the gel electrophoresis preparations (Masetto et al., 2014), being probably related to necrotic cell death. In this context, TUNEL detected necrotic cells which multiple free DNA ends generated especially after oxidant and toxic injury by activated endonucleases inserted labeled dUTP and it could be detected by fluorescence microscopy (Kelly et al., 2003).

In this way, cellular alterations, like cells in necrosis (Figure 3) were also confirmed in $5 \mathrm{~mm}$ long radicles. The inability to survive after drying and rehydration may be due to inhibition of DNA synthesis or a blocking of cells as a result of damage in cell-nuclei. Particularly, DNA damage arises as a consequence of endogenous ROS (reactive oxygen species), metabolic by-products, and breaks induced during DNA replication. Maintenance of genome integrity is critically important to prevent mutation prior to re-initiation of cell-cycle activity in the embryonic meristems (Waterworth et al., 2015). This is in agreement with our TUNEL results which showed a significant increase in DNA strand breaks, specially from $5 \mathrm{~mm}$ long radicles, as seen also in meristematic root cells, like cell in necrosis (Figure 3F). According to Huang et al. (2005), TUNEL test is based on the detection of DNA fragments through modified nucleotides incorporation (dUTP) by the Terminal deoxynucleotide transferase enzyme, whose nucleotides are fluorescent pigment highlighted; and the literature successfully reports the use of TUNEL test as a marker of cell death in roots submitted to abiotic stress in several species, such as barley (Katsuhara, 1997), corn (Xiong et al., 2006) and rice (Liu et al., 2007).

The data obtained from $C$. fissilis TUNEL-positive nuclei and the cellular alterations like necrosis are strongly related with the DNA degradation, as seen in Masetto et al. (2014) with the structural changes determined through the necrotic cells with compromised plasma membranes. This explains the cell injury events occurring in $C$. fissilis germinated seeds in

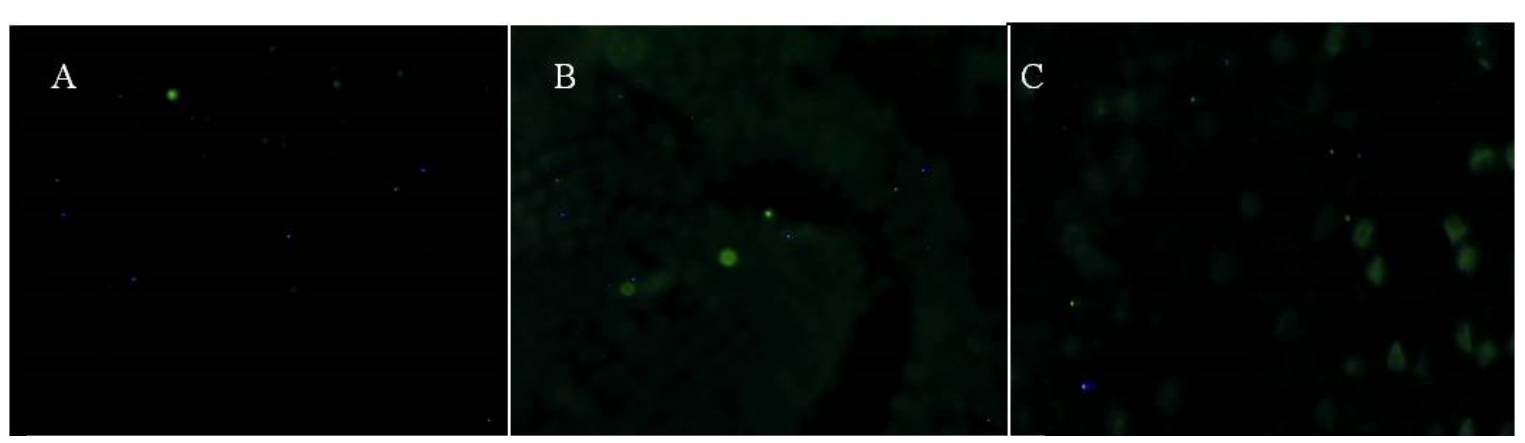

Figure 2. Representative images of TUNEL stained nuclei extracted from Cedrela fissilis germinated seeds with 1 (A), 2 (B) and 5 (C) mm long radicles, after incubation in PEG (-2.04 MPa), dehydration in silica gel to $10 \% \mathrm{MC}$ and rehydration. Green spots correspond to the TUNEL-positive nuclei. 


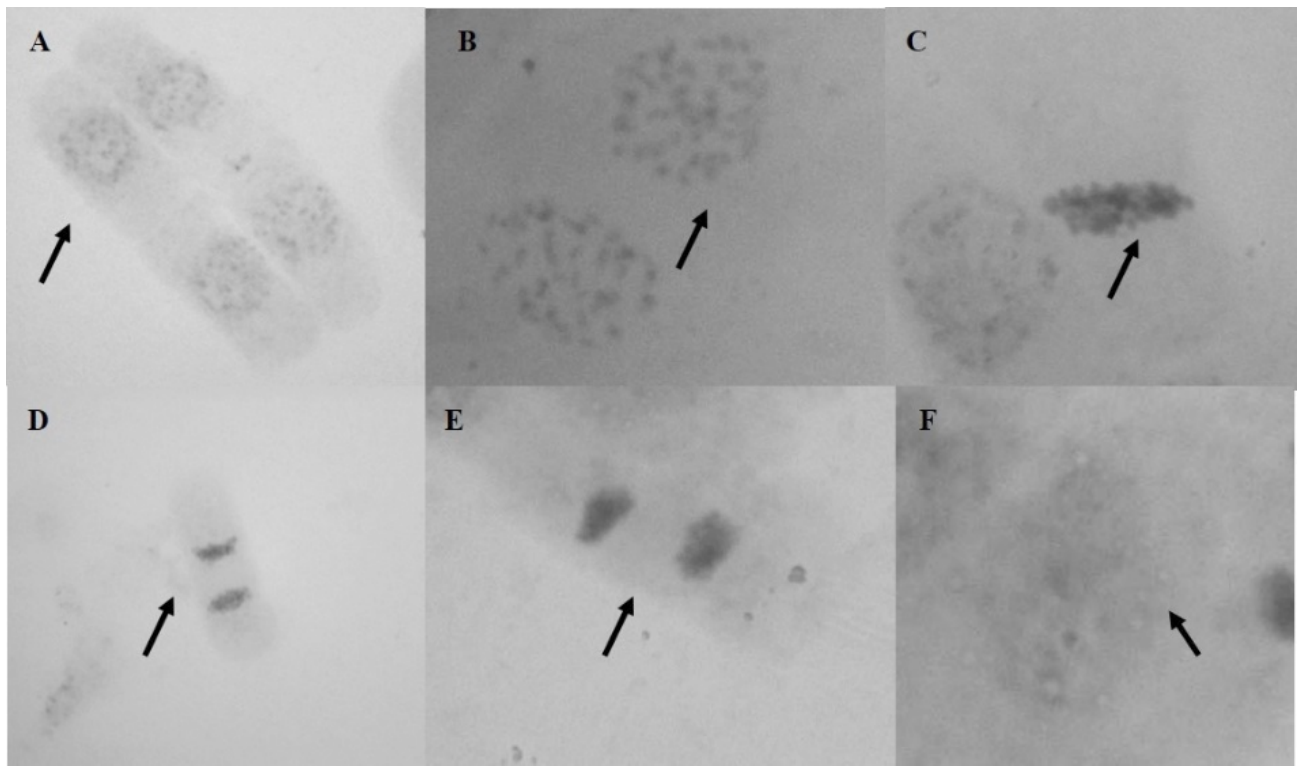

Figure 3. Meristematic root cells $(5-\mathrm{mm})$ in different mitosis phases and abnormalities probably induced by silica gel-dehydration following rehydration. Normal cells in: A (arrow) - interphase, B (arrow) - prophase, C (arrow) - metaphase, D (arrow) - anaphase, E (arrow) - telophase and F (arrow) - cell in necrosis.

the dry state and probably why these germinated seeds could not be resume their growth during rehydration.

\section{Conclusions}

DNA damage and cellular necrosis during drying are associated with radicle length and moisture content of $C$. fissilis germinated seeds.

\section{Acknowledgements}

We are thankful to the Laboratory of Plant Cytogenetics (Department of Biology - Universidade Federal de Lavras) and to Universidade Federal da Grande Dourados.

\section{References}

BERJAK, P.; PAMMENTER, N. Implications of the lack of desiccation tolerance in recalcitrant seeds. Frontiers in Plant Science, v.4, p.478, 2013. https://www.frontiersin.org/articles/10.3389/ fpls.2013.00478/full

BEWLY, J.D.; BRADFORD, K.J.; HILHORST, H.W.M.; NONOGAKI, H. Seeds: physiology of development, germination and dormancy. $3^{\text {rd }}$ ed. New York: Springer, 2013. 392p.

BRASIL. Ministério da Agricultura, Pecuária e Abastecimento. Regras para análise de sementes. Ministério da Agricultura, Pecuária e Abastecimento. Secretaria de Defesa Agropecuária. Brasília: MAPA/ACS, 2009. 395p. http://www.agricultura.gov.br/arq_editor/ file/2946_regras_analise_sementes.pdf
CARVALHO, C.R.; SARAIVA, L.S. An air drying technique for maize chromosomes without enzymatic maceration. Biotechnic \& Histochemistry, v.68, n.3, p.142-145, 1993. https://www.tandfonline. com/doi/abs/10.3109/10520299309104684

CHALLABATHULA, D.; PUTHUR, J.T.; BARTELS, D. Surviving metabolic arrest: photosynthesis during desiccation and rehydration in resurrection plants. Annals of the New York Academy of Sciences, v.1365, n.1, p.89-99, 2016. https://nyaspubs.onlinelibrary.wiley. com/doi/full/10.1111/nyas. 12884

DRESCH, D.M.; MASETTO, T.E.; SCALON, S.P.Q. Campomanesia adamantium (Cambess.) O. Berg seed desiccation: influence on vigor and nucleic acids. Anais da Academia Brasileira de Ciências, v.87, n.4, p.2217-2228, 2015. http:/www.scielo.br/ scielo.php?pid $=$ S0001-37652015000502217\&script $=$ sci_arttext

FARRANT, J.M.; MOORE, J.P. Programming desiccation-tolerance: from plants to seeds to resurrection plants. Current Opinion in Plant Biology, v.14, n.3, p.340-345, 2011. https://www.sciencedirect.com/ science/article/pii/S1369526611000306

FINCH-SAVAGE, W.E.; BASSEL, G.W. Seed vigour and crop establishment: extending performance beyond adaptation. Journal of Experimental Botany, v.67, n.3, p.567-591, 2015. https://academic. oup.com/jxb/article/67/3/567/2893341

GECHEV, T.S.; DINAKAR, C.; BENINA, M.; TONEVA, V.; BARTELS, D. Molecular mechanisms of desiccation tolerance in resurrection plants. Cellular and Molecular Life Sciences, v. 69, n. 19, p. $3175-3186,2012$. https://link.springer.com/article/10.1007/ s00018-012-1088-0 
HUANG, X.; HALICKA, H.D.; TRAGANOS, F. Cytometric assessment of DNA damage in relation to cell cycle phase and apoptosis. Cell Proliferation, v.38, n.4, p.223-243, 2005. https:// onlinelibrary.wiley.com/doi/full/10.1111/j.1365-2184.2005.00344.x

KATSUHARA, M. Apoptosis-like cell death in barley roots under salt stress. Plant Cell Physiology, v.38, n.9, p.1091-1093, 1997. https://academic.oup.com/pcp/article/38/9/1091/1809314

KELLY, K.J.; SANDOVAL, R.M.; DUNN, K.W.; MOLITORIS, B.A.; DAGHER, P.C. A novel method to determine specificity and sensitivity of the TUNEL reaction in the quantitation of apoptosis. American Journal of Physiology-Cell Physiology, v.284, n.5, p.C1309-C1318, 2003. https://www.physiology.org/doi/ abs/10.1152/ajpcell.00353.2002

KRANNER, I.; CHEN, H.; PRITCHARD, H.W.; PEARCE, S.R.; BIRTIC, S. Inter-nucleosomal DNA fragmentation and loss of RNA integrity during seed ageing. Plant Growth Regulation, v.63, n.1, p.63-72, 2011. http://link.springer.com/article/10.1007/s10725-0109512-7\#page-1

LEPRINCE, O.; BUITINK, J. Desiccation tolerance: from genomics to the field. Plant Science, v.179, n.6, p.554-564, 2010. https://www. sciencedirect.com/science/article/pii/S0168945210000415

LEPRINCE, O.; PELLIZZARO, A.; BERRIRI, S.; BUITINK, J. Late seed maturation: drying without dying. Journal of Experimental Botany, v. 68 , n. 4, p. 827-841, 2017. https://academic.oup.com/jxb/ article/68/4/827/2627439

LIU, S.H.; FU, B.Y.; XU, H.X.; ZHU, L.H.; ZHAI, H.Q.; LI, Z.K. Cell death in response to osmotic and salt stresses in two rice (Oryza sativa L.) ecotypes. Plant Science, v.172, n.5, p.897-902, 2007. https://www. sciencedirect.com/science/article/pii/S0168945206003670

MASETTO, T.E.; FARIA, J.M.R.; DAVIDE, A.C.; SILVA, E.A.A. Desiccation tolerance and DNA integrity in Eugenia pleurantha o. berg. (Myrtaceae) seeds. Revista Brasileira de Sementes, v.30, n.2, p.51-56, 2008. http://www.scielo.br/scielo. php?pid=S0101-31222008000200007\&script $=$ sci_arttext\&tlng=pt
MASETTO, T.E.; FARIA, J.M.; FRAIZ, A.C.R. Re-induction of desiccation tolerance after germination of Cedrela fissilis Vell. seeds. Anais da Academia Brasileira de Ciências, v.86, n.3, p.1273-1286, 2014. http://www.scielo.br/scielo.php?pid=S000137652014005030164\&script=sci_arttext\&tlng=pt

MASETTO, T.E.; FARIA, J.M.R.; FRAIZ, A.C.R. Loss and reestablishment of desiccation tolerance in the germinated seeds of Sesbania virgata (Cav.)(Pers.). Acta Scientiarum. Agronomy, v.37, n.3, p.313-320, 2015. http://www.scielo.br/scielo.php?pid=S1807$86212015000300313 \&$ script $=$ sci_arttext

MASETTO, T.E.; FRAIZ, A.C.R.; FARIA, J.M.R. Cell changes during the re-induction of desiccation tolerance in germinated seeds of Sesbania virgata (Cav.) Pers. Journal of Seed Science, v.38, n.3, p.254-258, 2016. http://www.scielo.br/scielo.php?pid=S231715372016005004104\&script=sci_arttext

MICHEL, B.E.; KAUFMANN, M.R. The osmotic potential of polyethylene glycol 6000. Plant Physiology, v.51, n.5, p.914-916, 1973. http://www.plantphysiol.org/content/51/5/914.short

WALTERS, C.; REILLEY, A.A.; REEVES, P.A.; BASZCZAK, J.; RICHARDS, C.M. The utility of aged seeds in DNA banks. Seed Science Research, v.16, n.3, p.169-178, 2006. https://www.cambridge.org/core/services/aop-cambridge-core/ content/view/531B6424E980A18F840DE9D913218AED/ S0960258506000195a.pdf/utility_of_aged_seeds_in_dna_banks.pdf

WATERWORTH, W.M.; BRAY, C.M.; WEST, C.E. The importance of safeguarding genome integrity in germination and seed longevity. Journal of Experimental Botany, v.66, n.12, p.3549-3558, 2015. https://academic.oup.com/jxb/article/66/12/3549/524229

XIONG, H.; LI, Y.; LI, L. A unique form of cell death occurring in meristematic root tips of completely submerged maize seedlings. Plant Science, v.171, n.5, p.624-631, 2006. 